\title{
Last chance for British Ass?
}

\section{The British Association for the Advancement of Science claims to have found a viable strategy for its own survival and for doing good works. It should be given the benefit of one last doubt.}

Those reading reports (see, for example, page 5) from the annual meeting of the British Association for the Advancement of Science (BAAS), this year at Southampton, will be tempted to say, "But we've heard it all before." And, of course, they will be correct. This is certainly not the first or even the second occasion since the Second World War when the organization has shaken itself by the scruff of its neck and declared to itself, and to anybody else prepared to listen, that things would be different from then on.

Indeed, in the early 1970 s, a grand reappraisal reached much the same conclusions as were advertised last week: there would be a periodical publication of some kind, more attention would be paid to matters of public importance (too often supposed to be, on that account alone, "controversial") and the organization would be more active in the yearlong intervals between its annual jamborees. Since then, there have been fitful endeavours of that kind, but not such as to stir the world.

Will it be different this time? And does it matter whether the BAAS succeeds or fails in making a mark in the present world?

The short answers are "Don't know", and "Yes". But the second must be qualified by the recognition that not all nineteenth-century organizations can expect a licence to survive in the twenty-first. The long answer has to do with history.

The BAAS was founded in 1832, the year of the Great Reform Bill in which Britain took the first steps towards universal electoral suffrage.-(A property qualification remained, and women had to wait almost a century for the vote.) The BAAS owes its existence to three influences: the ferment of interest in Britain in science and its application (Dalton was still active and the Industrial Revolution well under way), the interest of what are now called the chattering classes in the nature of the world (whence, eventually, this journal's existence) and the widespread (and correct) opinion that the Royal Society of London had become moribund.

For a good half-century, the BAAS was socially invaluable. So much is clear from the records of its early meetings, which were faithfully and often passionately recorded by the officials called "recorders" and then published in sufficient detail to be comprehensible. Its annual meetings were occasions when those of a philosophical temperament could learn what had happened to Dalton's atomic theory and what Lyell had been up to, when steel-masters could learn from metallurgists why it is that cast-iron has too much carbon to be malleable and when all and sundry could learn what was happening elsewhere; overseas guests were enthusiastically received.

The highlights of the BAAS's history in the nineteenth century are probably overdone. The great debate on Darwinism between T.H.Huxley and Bishop Wilberforce is commonly cited as an illustration of the BAAS's knack of making public the great controversies in science. It may have mattered much more to those who attended the annual meetings that they were among the few occasions when the then handful of dedicated researchers rubbed shoulders for a week with those whose livelihoods or peace of mind hung on what they had to say. For the BAAS's saving grace, then as now, is that its members are not required to be qualified at anything in particular.

Sadly, in the twentieth century shoulderrubbing acquired snobbish overtenes. People took to wearing dinner-jackets (tuxedos) to the annual dinners of their specialist sections - and kept up the practice long after it should have been clear to them that productive researchers did not own such garments. People would stay at hotels that matched their station in life - and those who could not afford hotels would stay with friends, or come only for a day.

Yet at the beginning of this century, the annual meetings were often memorable for what researchers said in public for the first time. (There is good reason to believe that the Lorentz contraction of the length of a relativistically moving object is known as the "Lorentz-Fitzgerald contraction" only because Sir Oliver Lodge told an annual meeting that the Irishman Lorentz "has been teaching that to his students for years".) By 1945 , with the emergence of a research profession in the universities and elsewhere, and the recognition that rapid publication is an obligation, they had become occasions active researchers were too busy to attend (except perhaps to give a talk and go away without reimbursement).

That does not mean that the annual meetings did not give pleasure to those who chose to attend them. Why would the audience have been there if it were otherwise? But, by the 1960s, the association behaved as if its function were to provide an annual occasion when upwards of 2,000 people (and 5,000 in a bumper year) could listen to the great, the good and the promising, taking in a few entertaining field excursions in the afternoons and an occasional dress-up dinner in the evenings.

The great crisis of the early 1970 s was occasioned by a shortage of funds and of goodwill. Then (as still) the annual meetings are made possible by the hospitality of universities, but universities were already short of funds. Worse, although there has always been a nucleus of administrative staff, the donkey-work of arranging scientific programmes was the responsibility of the recorders, who had ceased to be reporters and had become unpaid wheelers and dealers whose only reward was a modicum of the resemblance of power.

Twenty years ago, the response to crisis was typically English: committees were established, but were inadequately serviced. A handful of study groups was established to tackle issues of public importance. (The most successful of these, in which Nature had a hand, was an early study of the consequences of the then-new biology which had the nowSir Walter Bodmer as its chairman and included as members Mrs Shirley Williams, the politician and Dr (now Lord) Owen, afterwards Foreign Secretary and now the European Bosnian peace negotiator.) But these initiatives ran into the sand for lack of funds and will.

Could it be the same again? Let us hope not. Although, or perhaps because, the BAAS is marked by its origins in the nineteenth century, it would be a great misfortune if it went to the wall. But there is a sense in which it would be preferable to fail in a brave venture at survival than to be paralysed by an excess of caution, as it has been in the recent past. That is why nobody should complain that the annual meeting has been rechristened a "festival" or why this year's occasion was enlivened by a demonstration by sceptics that it is, indeed, possible to walk on hot coals. If that brings a larger audience willing to listen to more serious business, so much the better.

The greater difficulty will be that of sustaining some kind of activity between festivals. Not, of course, that there is a shortage of good works to accomplish. In luckier times, the BAAS might well have become the defender of British science against repressive governments. (Its apology has usually been that its council is too diverse to have a single opinion.) Even now, there is the whole issue of public education in science crying out for attention. And what of the wider European dimension of British science? With a world as full of important issues as the present, the BAAS should find a surprisingly substantial part of the research community willing to give it the benefit of one last doubt.

John Maddox 